\title{
Harmonisasi Kebijakan Pengelolaan Lingkungan Pesisir Lampung dalam Rezim Pengelolaan Berbasis Masyarakat
}

\author{
Mashuril Anwar dan Maya Shafira ${ }^{2}$
}

\begin{abstract}
Abstrak
Keterlibatan masyarakat dalam pengelolaan wilayah pesisir merupakan suatu keniscayaan untuk mewujudkan pengelolaan wilayah pesisir yang berkelanjutan dan menyejahterakan. Konsekuensinya, keserasian antar kebijakan pengelolaan wilayah pesisir terkait keterlibatan masyarakat menjadi penting, guna mewujudkan kepastian hukum bagi masyarakat untuk berperan aktif dalam pengelolaan wilayah pesisir. Oleh karena itu, artikel ini akan menganalisis keserasian antara kebijakan pengelolaan wilayah pesisir Lampung dengan peraturan perundang-undangan yang lebih tinggi maupun yang setara, khususnya ketentuan mengenai pelibatan masyarakat dalam pengelolaan wilayah pesisir. Kajian ini berkesimpulan bahwa kebijakan pemerintah Provinsi Lampung terkait keterlibatan masyarakat dalam pengelolaan wilayah pesisir masih disharmoni dengan peraturan perundang-undangan yang lebih tinggi maupun yang setara. Disharmoni ini menimbulkan ketidakpastian hukum, kesenjangan dalam peruntukan dan pemanfaatan sumber daya pesisir, dan keterbatasan akses masyarakat untuk berpartisipasi dalam pengelolaan wilayah Pesisir Lampung. Sehingga kebijakan pengelolaan wilayah pesisir Provinsi Lampung perlu direvisi melalui harmonisasi secara vertikal maupun horizontal, guna mewujudkan pengelolaan wilayah pesisir berbasis masyarakat.
\end{abstract}

Kata kunci: Lampung, Harmonisasi Kebijakan, Pengelolaan Pesisir

\section{Abstract}

Community involvement in the management of coastal areas is a necessity to realize sustainable and prosperous coastal management. Consequently, harmony between coastal area management policies related to community involvement is important to realize legal certainty for the community to play an active role in coastal area management. Therefore, this article will analyze the harmony between Lampung's coastal management policy and higher or equivalent regulations, specifically the provisions of community involvement in coastal management. This article concludes, Lampung's Provincial government policies of community involvement in coastal management are still in disharmony with higher and equivalent regulations. This disharmony raises legal uncertainty, gaps in the allocation and utilization of coastal resources, and limitation on community access to participate in the coastal management of Lampung Pro-

\footnotetext{
${ }^{1}$ Penulis adalah Mahasiswa Magister Ilmu Hukum Fakultas Hukum Universitas Lampung.

${ }^{2}$ Penulis adalah Dosen dan mahasiswa program Doktor Ilmu Hukum Fakultas Hukum Universitas Lampung.
} 
vince. Thus, Lampung's Province policy of coastal management needs to be revised through vertical and horizontal harmonization, to realize community-based coastal management.

Keywords: Lampung, Harmonization, Policy, Coastal Management

\section{Pendahuluan}

Luas perairan laut Provinsi Lampung diperkirakan mencapai $24.820 \mathrm{~km}$ dengan garis pantai sekitar $1.105 \mathrm{~km}$, yang terdiri dari empat wilayah pesisir yaitu Pantai Barat $(210 \mathrm{~km})$, Pantai Timur (270 km), Teluk Semangka (200 km), serta Teluk Lampung dan Selat Sunda (160 km). ${ }^{3}$ Selain itu jumlah penduduk yang mendiami wilayah pesisir Lampung diperkirakan mencapai 4.557.574 jiwa. ${ }^{4}$ Mengingat luasnya wilayah pesisir Lampung yang tersebar di beberapa kabupaten/kota dan banyaknya penduduk yang bermukim di wilayah pesisir, maka peran serta masyarakat sangat diperlukan untuk mewujudkan pengelolaan wilayah pesisir yang optimal dan berkelanjutan.

Secara nasional, keterlibatan masyarakat dalam pengelolaan wilayah pesisir diatur dalam beberapa instrumen hukum, antara lain: Undang-Undang Nomor 27 Tahun 2007 Juncto Undang-Undang Nomor 1 Tahun 2014 tentang Pengelolaan Wilayah Pesisir dan Pulau-Pulau Kecil (selanjutnya disebut UU
WP-3-K), Peraturan Menteri Kelautan dan Perikanan Nomor 40/PERMEN-KP/2014 tentang Peran Serta dan Pemberdayaan Masyarakat Dalam Pengelolaan Wilayah Pesisir dan Pulau-Pulau Kecil, dan Peraturan Menteri Kelautan dan Perikanan Nomor 23/PERMEN-KP/2016 tentang Perencanaan Pengelolaan Wilayah Pesisir dan Pulau-Pulau Kecil. Peran serta masyarakat dalam pengelolaan wilayah pesisir bertujuan untuk melaksanakan pengelolaan wilayah pesisir dengan tepat dan berdaya guna. Oleh karena itu, pemerintah berkewajiban memberdayakan masyarakat pesisir berdasarkan potensi, karakteristik, dan kebutuhannya, sehingga mereka dapat menentukan pilihan terbaik dalam memanfaatkan sumber daya pesisir. ${ }^{5}$ Lebih lanjut, mengingat potensi pesisir Lampung sebagai aset pembangunan daerah dan semakin maraknya permasalahan dalam pengelolaan wilayah pesisir antar sektor dan pemangku kepentingan ${ }^{6}$, maka rencana pembangunan kawasan pesisir menjadi sangat penting untuk di-

\footnotetext{
${ }^{3}$ Rencana Pembangunan Jangka Menengah Daerah (RPJMD) Provinsi Lampung 2015-2019, hlm. 15.

${ }^{4}$ Ibid., hlm. 31.

${ }^{5}$ Anak Agung Istri Ari Atu Dewi, "Model Pengelolaan Wilayah Pesisir Berbasis Masyarakat: Community Based Development," Jurnal Penelitian Hukum De Jure, Vol. 18, No. 2, Juni (2018), hlm. 172.

${ }^{6}$ Eksekutif Daerah WALHI Lampung, Pesisir Laut dan Pulau-Pulau Kecil Lampung, Kertas posisi isu pengelolaan wilayah pesisir laut dan pulau-pulau kecil Lampung, (Bandar Lampung: Eksekutif Daerah WALHI Lampung), hlm. 1.
} 
integrasikan. Berdasarkan UU WP-3-K, pemerintah daerah Provinsi dan Kabupaten/Kota melibatkan masyarakat dalam penyusunan rencana pengelolaan wilayah pesisir dan pulau-pulau kecil. ${ }^{7}$ Selain itu, Undang-Undang Nomor 23 Tahun 2014 sebagaimana telah diubah dengan Undang-Undang Nomor 9 Tahun 2015 tentang Pemerintahan Daerah, menentukan pengelolaan wilayah pesisir laut dan pulau-pulau kecil sejauh 12 mil di luar minyak dan gas bumi merupakan kewenangan pemerintah daerah provinsi. ${ }^{8}$ Selanjutnya, berdasarkan Surat Dirjen Pengelolaan Ruang Laut No. B-962/PRL/XI/2016 tanggal 23 November 2016 perihal Akselerasi Penetapan Perda RZWP-3-K, Gubernur menetapkan RZWP-3-K dengan Peraturan Daerah. Oleh karena itu, pemerintah Provinsi Lampung menetapkan Perda Provinsi Lampung Nomor 1 Tahun 2018 tentang Rencana Zonasi Wilayah Pesisir dan Pu-
lau-Pulau Kecil Provinsi Lampung 20182038 (selanjutnya disebut Perda Provinsi Lampung No. 1 Tahun 2018). Peraturan Daerah ini memuat arah kebijakan lintas sektor dalam pembangunan wilayah pesisir dan pulau-pulau kecil di Provinsi Lampung dalam upaya meningkatkan kesejahteraan masyarakat yang menggantungkan kehidupannya di wilayah pesisir. ${ }^{9}$ Namun, terdapat permasalahan ketidakharmonisan antar peraturan perundang-undangan dalam peraturan perencanaan pembangunan. ${ }^{10}$ Berbagai kegiatan di wilayah pesisir seperti pariwisata, lingkungan, perikanan, tata ruang, pertambangan dan sebagainya terkadang saling bertentangan, ${ }^{11}$ akibat tumpang-tindihnya peraturan perundang-undangan. ${ }^{12}$

Kerusakan di wilayah pesisir Lampung sendiri sudah cukup marak seperti abrasi, pencemaran, kekumuhan, dan kerusakan ekosistem terumbu karang. ${ }^{13}$

\footnotetext{
${ }^{7}$ Indonesia. Undang-Undang Pengelolaan Wilayah Pesisir dan Pulau-Pulau Kecil, UU No. 27 Tahun 2007, LN No. 84 Tahun 2007, TLN No. 4739, ps. 14 ayat (2) menyatakan mekanisme penyusunan RSWP-3-K, RZWP-3-K, dan RAPWP-3-K pemerintah Provinsi dan pemerintah daerah Kabupaten/Kota dilakukan dengan melibatkan masyarakat.

${ }^{8}$ Indonesia. Undang-Undang Pemerintahan Daerah, UU No. 23 Tahun 2014, LN No. 244 Tahun 2014, TLN No. 5587, ps. 27 dan Lampiran huruf Y.

${ }^{9}$ Indonesia. Pemerintah Provinsi Lampung, Peraturan Daerah Provinsi Lampung tentang Rencana Zonasi Wilayah Pesisir dan Pulau-Pulau Kecil, Perda Provinsi Lampung No. 1 Tahun 2018, LD No. 1 Tahun 2018, penjelasan umum.

${ }^{10}$ Maret Priyanta. "Pembaharuan dan Harmonisasi Peraturan Perundang-Undangan Bidang Lingkungan dan Penataan Ruang Menuju Pembangunan Berkelanjutan," Hasanudin Law Review, Vol. 1, No. 3 (Desember 2015), hlm. 340.

${ }^{11}$ Tommy Cahya Trinanda. "Pengelolaan Wilayah Pesisir Indonesia dalam Rangka Pembangunan Berbasis Pelestarian Lingkungan," Matra Pembaharuan: Jurnal Inovasi Kebijakan, Vol. 1, No. 2 (2017), hlm. 81.

${ }^{12}$ Luky Adrianto dkk, Analisis dan Evaluasi Hukum tentang Pengelolaan Wilayah Pesisir dan Pulau-Pulau Kecil, (Jakarta: Badan Pembinaan Hukum Nasional Kementerian Hukum dan HAM RI, 2015), hlm. 11.

${ }^{13}$ Lembaga Penelitian dan Pengabdian Kepada Masyarakat Institut Pertanian Bogor (LPPM IPB), Kajian Gerakan Membangun Pesisir Lampung Berdaya Guna "GERBANG PELANA", (Bogor: LPPM IPB, 2017), hlm. 1.
} 
Salah satu penyebab kerusakan wilayah pesisir Lampung adalah kebijakan yang kurang memperhatikan keterlibatan masyarakat sebagai aktor utama dalam pengelolaan wilayah pesisir. ${ }^{14}$ Oleh karena itu, artikel ini akan menganalisis keserasian antara kebijakan pengelolaan wilayah pesisir Lampung yang dimuat dalam Perda Provinsi Lampung Nomor 1 Tahun 2018, dengan peraturan perundang-undangan yang lebih tinggi maupun yang setara terkait keterlibatan masyarakat dalam pengelolaan wilayah pesisir. Guna menjawab permasalahan tersebut, artikel ini dibagi menjadi beberapa bagian. Pada bagian II akan diuraikan kerangka konseptual harmonisasi hukum. Bagian III akan menganalisis harmonisasi kebijakan pengelolaan wilayah pesisir Lampung dalam rezim pengelolaan berbasis masyarakat. Selanjutnya, pada bagian IV akan menguraikan urgensi harmonisasi kebijakan pengelolaan wilayah pesisir Lampung terkait pelibatan masyarakat dalam pengelolaan wilayah pesisir. Terakhir, tulisan ini ditutup dengan kesimpulan pada bagian $\mathrm{V}$.

\section{Kerangka Konseptual Harmoni- sasi Hukum}

Harmonisasi hukum merupakan upaya penciptaan keselarasan antar norma hukum dalam peraturan perundang-undangan ke dalam satu kesatuan kerangka hukum nasional. ${ }^{15}$ Penciptaan produk hukum yang selaras bukanlah perkara mudah, karena harus menggali nilai-nilai dalam masyarakat yang memerlukan waktu dan biaya. Pada umumnya, pengharmonisan hukum di Indonesia dilakukan dengan cara sebagai berikut: ${ }^{16}$

1. Memastikan rancangan peraturan perundang-undangan memuat nilai-nilai Pancasila;

2. Memastikan ketentuan UUD Tahun 1945 yang memerintahkan pembentukan peraturan perundang-undangan telah dimuat dalam rancangan peraturan perundang-undangan dan selaras dengan prinsip penyelenggaraan negara dalam UUD Tahun 1945;

3. Menggunakan istilah hukum secara baik dan konsisten;

4. Meneliti secara cermat keserasian antara materi muatan rancangan peraturan perundang-undangan dengan peratur-

\footnotetext{
${ }^{14}$ Anak Agung Isteri Ari Atu Dewi, Op. Cit., hlm. 173.

${ }^{15}$ Indriati Amarini. “Evaluasi Aktualisasi Pancasila Melalui Harmonisasi Hukum," Jurnal Kosmik Hukum, Vol. 17, No. 2 (Juni 2017), hlm. 86.

${ }^{16}$ Insan Tajali Nur. "Memantapkan Landasan Hukum Formil Sebagai Alat Sinkronisasi Dan Harmonisasi Peraturan Perundang-Undangan," Yuriska: Jurnal Ilmu Hukum, Vol. 10, No. 2 (Agustus 2018), hlm. 162.
} 
an perundang-undangan lain yang lebih tinggi maupun yang setara;

5. Memastikan asas peraturan perundang-undangan telah terakomodasi dengan baik dalam rancangan peraturan perundang-undangan;

6. Memastikan bahwa penyusunan rancangan peraturan perundang-undangan telah sesuai dengan teknik perancangan peraturan perundang-undangan; dan

7. Memastikan bahasa yang digunakan dalam perumusan norma telah sesuai dengan kaidah bahasa Indonesia yang baik dan benar.

Idealnya, harmonisasi hukum dilakukan ketika perancangan peraturan perundang-undangan. Harmonisasi hukum meliputi dua aspek, yaitu: pertama, pengharmonisan materi muatan rancangan undang-undang dengan Pancasila, UUD RI Tahun 1945, undang-undang, dan asas pembentukan peraturan perundang-undangan; kedua, pengharmonisan rancangan undang-undang dengan teknik penyusunan peraturan perundang-undangan. ${ }^{17}$ Upaya pengharmonisan itu sendiri dibagi menjadi dua, yakni harmonisasi vertikal dan harmonisasi horizontal. Harmonisasi vertikal merupakan upaya penyerasian antara peraturan perundang-undangan dalam hierarki yang berbeda. Harmonisasi vertikal didasarkan pada asas lex superior derogat legi inferiori, yang berarti peraturan perundang-undangan yang lebih tinggi menyampingkan peraturan perundang-undangan yang lebih rendah. ${ }^{18}$ Harmonisasi vertikal dilakukan dengan cara menelaah norma-norma peraturan yang lebih tinggi, sehingga materi yang diatur dalam penyusunan peraturan perundang-undangan tidak bertentangan dengan peraturan perundang-undangan di atasnya. ${ }^{19}$ Harmonisasi vertikal peraturan perundang-undangan berperan penting untuk membentuk peraturan perundang-undangan yang saling terkait dan mencegah judicial review yang membutuhkan biaya, waktu, pikiran, dan tenaga. ${ }^{20}$

Sedangkan, harmonisasi horizontal adalah upaya penyerasian terhadap peraturan perundang-undangan yang setara. ${ }^{21}$ Harmonisasi horizontal berangkat dari asas lex posterior derogat

${ }^{17} \mathrm{Ibid} ., \mathrm{hlm} .162$.

${ }^{18}$ Ari Iswahyuni. “Kedudukan Ancaman Pidana Minimal Dalam Undang-Undang Nomor 35 Tahun 2009 tentang Narkotika Pasca Dikeluarkannya Surat Edaran Mahkamah Agung Nomor 3 Tahun 2015," Jurnal Panorama Hukum, Vol. 3, No. 1 (Juni 2018), hlm. 21.

${ }^{19}$ Novira Maharani Sukma. "Analisis Yuridis Pembatalan Perda Oleh Menteri Dalam Negeri," Jurnal Ilmiah Galuh Justisi, Vol. 5, No. 1, (Maret 2017), hlm. 6.

${ }^{20}$ Ibid.

${ }^{21}$ Sapto Budoyo, “Konsep Langkah Sistemik Harmonisasi Hukum dalam Pembentukan Peraturan Perundang-Undangan," Jurnal Ilmiah Civis, Vol. IV, No. 2 (Juli 2014), hlm. 607. 
legi priori, yang berarti peraturan perundang-undangan yang baru menyampingkan peraturan perundang-undangan yang lama. ${ }^{22}$ Selain itu, harmonisasi horizontal juga didasarkan pada asas lex specialis derogat legi generalis, yakni peraturan perundang-undangan yang khusus menyampingkan peraturan perundang-undangan yang umum. $^{23}$ Dalam praktiknya, harmonisasi horizontal berdasarkan asas lex posterior derogat legi priori dilakukan terhadap peraturan perundang-undangan yang berada pada hierarki yang setara dan diatur dalam ketentuan penutup. ${ }^{24}$ Sedangkan, harmonisasi horizontal berdasarkan asas lex specialis derogat legi generalis diperlukan guna membentuk peraturan perundang-undangan yang berkarakter khusus untuk mencapai tujuan tertentu. ${ }^{25}$ Harmonisasi horizontal dilakukan dengan cara memastikan norma yang diatur dalam suatu peraturan perundang-undangan selaras atau tidak tumpang tindih antar peraturan perundang-undangan yang setara. ${ }^{26}$ Sehingga setiap peraturan perundang-undangan menjadi bagian integral dari keseluruhan sistem legislasi. ${ }^{27}$

\section{Harmonisasi Kebijakan Penge- lolaan Wilayah Pesisir Lampung Dalam Rezim Pengelolaan Ber- basis Masyarakat}

Harmonisasi hukum terkait pengelolaan wilayah pesisir berbasis masyarakat mempunyai peranan penting untuk menghindari pertentangan dan tumpang tindih peraturan. ${ }^{28}$ Berdasarkan hasil identifikasi, saat ini terdapat 28 produk hukum nasional yang mengatur pengelolaan wilayah pesisir. ${ }^{29}$ Produk hukum tersebut terdiri dari 2 Undang-Undang, 3 Peraturan Presiden, 2 Peraturan Menteri, dan 21 Peraturan Daerah Provinsi, termasuk Provinsi Lampung, sebagaimana grafik berikut ini:

\footnotetext{
${ }^{22}$ Ferry Irawan Febriansyah. “Konsep Pembentukan Peraturan Perundang-Undangan Di Indonesia," Jurnal Perspektif, Vol. 21, No. 3 (September 2016), hlm. 223.

${ }^{23}$ Angreime Igir. "Pembatalan Terhadap Peraturan Daerah Menurut Undang-Undang Nomor 23 Tahun 2104," Lex Privatum, Vol. 5, No. 3 (Mei 2017): hlm. 62.

${ }^{24}$ Soegiyono, "Pentingnya Harmonisasi Pembentukan Peraturan Perundang-Undangan", https:/ / puskkpa.lapan.go.id/files_arsip/Soegiyono_Pentingnya_Harmoniasi_2015.pdf, diakses tanggal 1 April 2020.

${ }^{25}$ Sapto Budoyo, Op. Cit., hlm. 616.

${ }^{26}$ Soegiyono, Op. Cit.

${ }^{27}$ Heryandi dkk. "Harmonization of Village Development Planning Law in Lampung Coastal in the Spatial Planning Regime," Journal of Law, Policy, and Globalization, Vol. 70, (2018), hlm. 17.

${ }^{28}$ Sapto Budoyo, Op. Cit., hlm. 620.

${ }^{29}$ UU No. Tahun 2007 juncto UU No. 1 Tahun 2014 tentang Pengelolaan Wilayah Pesisir dan Pulau-Pulau Kecil, Perpres No. 121 Tahun 2012 tentang Rehabilitasi Wilayah Pesisir dan Pulau-Pulau Kecil, Perpres No. 122 Tahun 2012 tentang Reklamasi di Wilayah Pesisir dan Pulau-Pulau Kecil, PERPRES No. 73 Tahun 2015 tentang Pelaksanaan Koordinasi Pengelolaan Wilayah Pesisir dan Pulau-Pulau Kecil Tingkat Nasional, Permen Kelautan dan Perikanan Nomor 40/PERMEN-KP/2014 tentang Peran Serta Dan Pemberdayaan Masyarakat Dalam Pengelolaan Wilayah Pesisir Dan Pulau-Pulau Kecil, Permen
} 


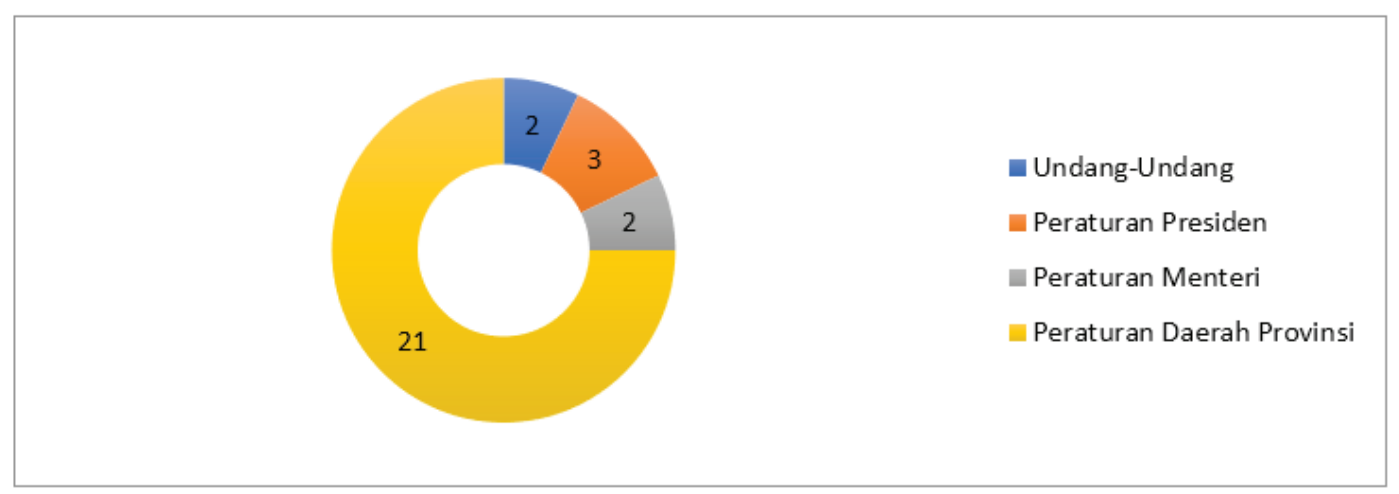

\section{Gambar 2. Grafik produk hukum nasional pengelolaan wilayah pesisir Sumber: Data diolah, 2019}

Pelibatan masyarakat dalam pengelolaan wilayah pesisir diatur dalam beberapa produk hukum nasional, yaitu Undang-Undang Nomor 27 tahun 2007 tentang Pengelolaan Wilayah Pesisir dan Pulau-Pulau Kecil, Undang-Undang Nomor 1 Tahun 2014 tentang Perubahan atas Undang-Undang Nomor 27 tahun 2007 tentang Pengelolaan Wilayah Pesisir dan Pulau-Pulau Kecil, Peraturan Menteri Kelautan dan Perikanan Nomor
40/PERMEN-KP/2014 tentang Peran Serta dan Pemberdayaan Masyarakat dalam Pengelolaan Wilayah Pesisir dan Pulau-Pulau Kecil, Peraturan Menteri Kelautan dan Perikanan Nomor 23/ PERMEN-KP/2016 tentang Perencanaan Pengelolaan Wilayah Pesisir Dan Pulau-Pulau Kecil. Secara umum, peraturan perundang-udangan tersebut akan diuraikan secara singkat pada bahasan berikut:

Kelautan dan Perikanan Nomor 23/PERMEN-KP/2016 tentang Perencanaan Pengelolaan Wilayah Pesisir Dan Pulau-Pulau Kecil. Selanjutnya terdapat 21 peraturan daerah (Perda) tentang rencana zonasi wilayah pesisir dan pulau-pulau kecil yakni Perda Provinsi Sulawesi Utara No. 1 Tahun 2017, Perda Provinsi Sulawesi Tengah No. 10 Tahun 2017, Perda Provinsi Sulawesi Barat No. 6 Tahun 2017, Perda Provinsi Sumatera Barat No. 10 Tahun 2017, Perda Provinsi Nusa Tenggara Timur No. 4 Tahun 2017, Perda Provinsi Nusa Tenggara Barat No. 12 Tahun 2017, Perda Provinsi Lampung No. 1 Tahun 2018, Perda Provinsi Jawa Tengah No. 13 Tahun 2018, Perda Provinsi Sulawesi Tenggara No. 9 Tahun 2018, Perda Provinsi Gorontalo No. 4 Tahun 2018, Perda Provinsi Kalimantan Selatan No. 13 Tahun 2018, Perda Provinsi Maluku Utara No. 2 Tahun 2018, Perda Provinsi Maluku No. 1 Tahun 2018, Perda Provinsi Jawa Timur No. 1 Tahun 2018, Perda Provinsi Diy No. 9 Tahun 2018, Perda Provinsi Kalimantan Utara No. 4 Tahun 2018, Perda Provinsi Sulawesi Selatan No. 2 Tahun 2019, Perda Provinsi Jawa Barat No. 5 Tahun 2019, Perda Provinsi Sumatera Utara No. 4 Tahun 2019, Perda Provinsi Kalimantan Barat No. 1 Tahun 2019, Dan Perda Provinsi Kalimantan Tengah No. 1 Tahun 2019. 
1. Undang-Undang Nomor 27 Tahun 2007 juncto Undang-Undang Nomor 1 Tahun 2014 tentang Pengelolaan Wilayah Pesisir dan Pulau-Pulau Kecil

Pembentukan Undang-Undang Nomor 27 Tahun 2007 didasari oleh kerentanan kerusakan wilayah pesisir akibat aktivitas manusia dalam memanfaatkan sumber daya pesisir. ${ }^{30}$ Sehingga, salah satu tujuannya adalah untuk meningkatkan kesejahteraan sosial, ekonomi, dan budaya masyarakat pesisir. ${ }^{31}$ Tujuan itu dapat dicapai dengan salah satunya pengelolaan wilayah pesisir dan pulau-pulau kecil yang berasaskan pada peran serta masyarakat yang terdiri dari masyarakat adat dan masyarakat lokal yang bermukim di wilayah pesisir. ${ }^{32}$

Peran serta masyarakat dalam pengelolaan wilayah pesisir dimulai dari tahap penyusunan rencana, pelaksanaan, pengawasan, hingga pengendalian pengelolaan wilayah pesisir. ${ }^{33}$ Hak, kewajiban, dan peran serta masyarakat dalam pengelolaan wilayah pesisir pun sudah diatur di dalamnya. ${ }^{34}$ Tidak hanya itu, pemerintah wajib memberdayakan masyarakat dalam pengelolaan wilayah pesisir. ${ }^{35}$ Berdasarkan uraian di atas, ketentuan Undang-Undang Nomor 27 Tahun 2007 sesuai dengan prinsip co-management. Co-management atau pendekatan kemitraan merupakan bentuk partisipasi aktif semua anggota masyarakat dan pihak terkait lainnya. Pada dasarnya Prinsip co-management merupakan perencanaan, pengorganisasian, pelaksanaan, dan pengawasan secara integratif. ${ }^{36} \mathrm{Co}$ -management menghendaki berbagai pemangku kepentingan, pemerintah, dan masyarakat terlibat dalam pengelolaan sumber daya pesisir. Konsep ini mensyaratkan adanya kolaborasi antara pemerintah dan pemangku kepentingan khususnya masyarakat lokal dalam pengelolaan wilayah pesisir. ${ }^{37}$

Pada tahun 2014, undang-undang ini mengalami perubahan dengan diundangkannya Undang-Undang Nomor 1 Tahun 2014. Undang-Undang Nomor 1 Tahun 2014 mengharuskan pemerintah daerah Provinsi dan Kabupaten/ Kota untuk melaksanakan perencanaan

${ }^{30}$ Indonesia. Undang-Undang Pengelolaan Wilayah Pesisir dan Pulau-Pulau Kecil, UU No. 27 Tahun 2007, LN No. 84 Tahun 2007, TLN No. 4739, ketentuan umum.

${ }^{31}$ Ibid., ps. 4 huruf d.

${ }^{32}$ Ibid., ps. 3 huruf g.

${ }^{33}$ Ibid., ps. 4 huruf d.

${ }^{34}$ Ibid., bab XI ps. 60-62.

${ }^{35}$ Ibid., ps. 63.

${ }^{36}$ Taufik Kurniawan, "Co-Management Intern Stakeholder As A Public-Private Partnership Model in Development Program for Rural Infrastructure," Jurnal Adbispreneur, Vol. 2, No. (Agustus 2017), hlm. 153.

${ }^{37}$ Siti Arieta, "Co-Management dalam Arena Perikanan Napoloen Wrasse di Kabupaten Kepulauan Anambas Tinjaun Teoritis dalam Mewujudkan Keberlanjutan Lingkungan Maritim," Jurnal PPNS, Vol. 4, No. 1 (Desember 2019), hlm. 124. 
pengelolaan kawasan pesisir dan pulau-pulau kecil secara terpadu, dengan melibatkan pemangku kepentingan terkait, terutama masyarakat sebagai pengguna langsung rencana strategis, rencana zonasi, rencana kelola, dan rencana aksi. Selain itu, Undang-Undang Nomor 1 Tahun 2014 ini sejalan dengan konsep pembangunan berbasis masyarakat lokal. ${ }^{38}$ Hal ini dapat dilihat dari pasal 60 Undang-Undang Nomor 1 Tahun 2014 yang mengatur mengenai hak masyarakat untuk mengusulkan wilayah penangkapan ikan secara tradisional dan mengusulkan wilayah masyarakat hukum adat dalam RZWP-3-K. Artinya masyarakat berhak mengambil bagian dalam penyusunan RZWP-3-K. ${ }^{39}$ Lebih lanjut, pemerintah dan pemerintah daerah berkewajiban mendorong kegiatan usaha masyarakat melalui pemberian akses teknologi dan informasi, peningkatan kapasitas, permodalan, jaminan pasar, infrastruktur, dan sebagainya. ${ }^{40}$ Ketentuan ini merupakan salah satu cara untuk meningkatkan kesejahteraan masyarakat pesisir yakni dengan mendorong kegiatan usahanya sebagai bagian pemberdayaan masyarakat pesisir yang umumnya menyangkut pemberian keterampilan, kesempatan, dan pengetahuan. ${ }^{41}$

\section{Peraturan Menteri Kelautan dan Perikanan Nomor 40/PERMEN- -KP/2014 tentang Peran Serta dan Pemberdayaan Masyarakat Dalam Pengelolaan Wilayah Pe- sisir dan Pulau-Pulau Kecil}

Peraturan Menteri Kelautan dan Perikanan Nomor 40/PERMEN-KP/2014 (Permen KP Nomor 40/PERMEN-KP/2014) merupakan respons akan pentingnya peran serta masyarakat dalam pengelolaan wilayah pesisir. ${ }^{42}$ Permen ini dibentuk dengan memperhatikan dinamika peran serta dan pemberdayaan masyarakat dalam pengelolaan wilayah pesisir. ${ }^{43}$ Oleh karena Permen ini merupakan satu-satunya peraturan yang secara khusus memuat keterlibatan masyarakat dalam pengelolaan wilayah

${ }^{38}$ Aprillia Theresia dkk, Pembangunan Berbasis Masyarakat: Acuan bagi Praktisi, Akademisi, dan Pemerhati Pengembangan Masyarakat, (Bandung: Alfabeta, 2014), hlm. 28.

${ }^{39}$ Indonesian Center for Environmental Law. "Kerangka Hukum: Pelibatan Masyarakat dalam Penyusunan Rencana Zonasi Wilayah Pesisir dan Pulau-Pulau Kecil," https:/ /icel.or.id/wp-content/ uploads/lembar-informasi-pelibatan-masyarakat.pdf, diakses pada 3 April 2020.

${ }^{40}$ Indonesia. Undang-Undang Pengelolaan Wilayah Pesisir dan Pulau-Pulau Kecil. UU No. 1 Tahun 2014. LN No. 2 Tahun 2014. TLN No. 5490, ps. 63 ayat (2).

${ }^{41}$ Sopyan, Y. "Corporate Social Responsibility (CSR) Sebagai Implementasi Fikih Sosial Untuk Pemberdayaan Masyarakat," AHKAM : Jurnal Ilmu Syariah, Vol. 14, No. 1 (Januari 2014), hlm. 57.

${ }^{42}$ Anak Agung Istri Ari Atu Dewi. "Model Pengelolaan Wilayah Pesisir Berbasis Masyarakat: Community Based Development," Jurnal Penelitian Hukum De Jure, Vol. 18, No. 2 (Juni 2018), hlm. 171.

${ }^{43}$ Indonesia. Undang-Undang Pengelolaan Wilayah Pesisir dan Pulau-Pulau Kecil, UU No. 27 Tahun 2007, LN No. 84 Tahun 2007, TLN No. 4739, bagian menimbang. 
pesisir, Permen ini seyogianya menjadi dasar setiap peraturan daerah di bidang pengelolaan wilayah pesisir. ${ }^{44}$

Hal itu juga terlihat secara jelas dalam tujuan Permen KP Nomor 40/PERMEN-KP/2014 yang menyatakan bahwa maksud Permen ini adalah menjadi dasar bagi pemerintah dan pemerintah daerah, pemangku kepentingan dan masyarakat untuk mewujudkan peran serta dan pemberdayaan masyarakat dalam PWP-3-K. ${ }^{45}$ Permen ini juga mengamanatkan bahwa masyarakat mempunyai kesempatan yang sama untuk berperan serta dalam pengelolaan wilayah pesisir dan pulau-pulau kecil (PWP-3-K), mulai dari tahap perencanaan, pelaksanaan, hingga pengawasan. ${ }^{46}$ Pada tahap perencanaan, masyarakat berperan dalam mengusulkan penyusunan RSWP-3-K, RZWP-3-K, RPWP-3-K, dan RAPWP-3-K dan menyusun RSWP-3-K, RZWP-3-K, RPWP-3-K, dan RAPWP-3-K. ${ }^{47}$ Sedangkan, pada tahap pelaksanaan, masyarakat berperan dalam menjaga konsistensi pada perencanaan PWP-3-K yang telah disepakati, melakukan mitigasi bencana terhadap kegiatan yang berpotensi mengakibat- kan kerusakan wilayah pesisir dan pulau-pulau kecil, melakukan kegiatan pengelolaan sumber daya pesisir dan pulau-pulau kecil memperhatikan keberadaan masyarakat hukum adat dan tidak bertentangan dengan ketentuan peraturan perundang-undangan, menjaga, memelihara dan meningkatkan efisiensi dan efektivitas serta kelestarian fungsi lingkungan di wilayah pesisir dan pulau-pulau kecil, memantau pelaksanaan rencana Pengelolaan Wilayah Pesisir dan Pulau- Pulau Kecil, dan memberikan informasi atau laporan dalam pelaksanaan pemanfaatan terhadap PWP-3-K. ${ }^{48}$ Sementara, pada tahap pengawasan, masyarakat berperan dalam melaporkan kerugian yang menimpa dirinya yang berkaitan dengan pelaksanaan Pengelolaan Wilayah Pesisir dan Pulau-Pulau Kecil, melaporkan dugaan pencemaran, pencemaran, dan/atau perusakan Wilayah Pesisir dan Pulau-Pulau Kecil yang merugikan kehidupannya, dan melaporkan terjadinya bahaya, pencemaran, dan/ atau kerusakan lingkungan di Wilayah Pesisir dan Pulau-Pulau Kecil. ${ }^{49}$

\footnotetext{
${ }^{44}$ Anak Agung Istri Ari Atu Dewi, Op. Cit., hlm. 72.

${ }^{45}$ Indonesia. Kementerian Kelautan dan Perikanan Republik Indonesia, Peraturan Menteri Kelautan dan Perikanan tentang Peran Serta dan Pemberdayaan Masyarakat dalam Pengelolaan Wilayah Pesisir dan Pulau-Pulau Kecil, Permen KP No. 40/PERMEN-KP/2014, BN Tahun 2014 No. 1369, Pasal 3 ayat (1).

${ }^{46}$ Ibid., ps. 4.

${ }^{47}$ Ibid., ps. 5 huruf a.

${ }^{48} \mathrm{Ibid}$. ., ps. 8.

${ }^{49}$ Ibid., ps. 9.
} 
Lebih lanjut, Pemerintah berkewajiban menyelenggarakan pembinaan dalam rangka peningkatan peran serta masyarakat dalam pengelolaan wilayah pesisir. ${ }^{50}$ Pembinaan tersebut dilakukan melalui bimbingan, bantuan hukum, sosialisasi, pendidikan, pelatihan, dan penyuluhan. ${ }^{51}$ Pemerintah Provinsi Lampung sendiri telah melakukan beberapa upaya pembinaan guna meningkatkan peran serta masyarakat dalam pengelolaan wilayah pesisir Lampung, di antaranya adalah program GERBANG PELANA (Gerakan Membangun Masyarakat Pesisir yang Berdaya Guna), pengembangan kapasitas masyarakat, program pengelolaan pesisir berbasis masyarakat, dan program keberlanjutan daerah pengembangan laut berbasis masyarakat. ${ }^{52} \mathrm{Na}-$ mun, apabila dilihat dari kondisi wilayah pesisir Lampung yang masih dalam posisi marginal, ${ }^{53}$ minim infrastruktur, belum berkembangnya perekonomian masyarakat, dan belum berdayanya kehidupan masyarakat pesisir Lampung, upaya-upaya pembinaan tersebut belum terealisasi secara maksimal. ${ }^{54}$

\section{Peraturan Menteri Kelautan dan Perikanan Nomor 23/PERMEN- -KP/2016 tentang Perencanaan Pengelolaan Wilayah Pesisir dan Pulau-Pulau Kecil}

Peraturan Menteri Kelautan dan Perikanan Nomor 23/PERMEN-KP/2016 (Permen KP No. 23/PERMEN-KP/2016) merupakan tindak lanjut dari ketentuan Pasal 7 ayat (2) Undang-Undang Nomor 27 Tahun 2007 juncto Undang-Undang Nomor 1 Tahun 2014 tentang Pengelolaan Wilayah Pesisir dan Pulau-Pulau Kecil.55 Permen KP No. 23/PERMEN-KP/2016 bertujuan untuk mewujudkan Perencanaan Pengelolaan Wilayah Pesisir dan Pulau-pulau Kecil secara terpadu pada tingkat Pemerintah Daerah provinsi. ${ }^{56}$ Dalam mewujudkan tujuan tersebut, Permen ini menganut beberapa prinsip, yang salah satunya, pelibatan peran serta masyarakat setempat. ${ }^{57}$ Artinya dalam pengelolaan wilayah pesisir masyarakat

\footnotetext{
${ }^{50}$ Ibid., ps. 19 ayat (1).

${ }^{51}$ Ibid., ps. 19 ayat (2).

${ }^{52}$ Lembaga Penelitian dan Pengabdian Kepada Masyarakat Institut Pertanian Bogor (LPPM IPB), Kajian Gerakan Membangun Pesisir Lampung Berdaya Guna "GERBANG PELANA", (Bogor: LPPM IPB, 2017), hlm. 4.

${ }_{53}$ Arif Satria, Pengantar Sosiologi Masyarakat Pesisir, (Jakarta: Yayasan Pustaka Obor Indonesia, 2015), hlm. 1.

${ }^{54}$ LPPM IPB., Op. Cit. hlm. 2.

${ }^{55}$ Indonesia. Kementerian Kelautan dan Perikanan Republik Indonesia, Peraturan Menteri Kelautan dan Perikanan tentang Perencanaan Pengelolaan Wilayah Pesisir dan Pulau-Pulau Kecil, Permen KP No. 23/PERMEN-KP/2016, BN Tahun 2016 No. 1138, Pasal 7 ayat (2) menyatakan norma, standar, dan pedoman penyusunan perencanaan pengelolaan wilayah pesisir dan pulau-pulau kecil diatur dengan peraturan menteri.

${ }^{56}$ Ibid., ps. 2 ayat (2).

${ }^{57} \mathrm{Ibid} .$, ps. 3 huruf d.
} 
harus selalu diberitahu mengenai apa yang sedang dan telah direncanakan. ${ }^{58}$ Aspirasi masyarakat merupakan sumber data primer dalam penyusunan rencana zonasi wilayah pesisir. ${ }^{59}$ Oleh karena itu, peran serta masyarakat setempat perlu dikedepankan dalam perencanaan pengelolaan wilayah pesisir. ${ }^{60}$ Lebih lanjut, dalam penyusunan RZWP-3-K pemerintah provinsi mengacu pada wilayah masyarakat hukum adat dan kearifan lokal. ${ }^{61}$ Demikian pula dalam penyusunan peraturan pemanfaatan ruang, wilayah masyarakat hukum adat dan kearifan lokal di perairan pesisir dan pulau-pulau kecil harus diperhatikan. ${ }^{62}$

Lebih jauh lagi, pelibatan masyarakat dalam pengelolaan wilayah pesisir juga diatur dalam beberapa peraturan daerah Provinsi Lampung, yaitu: Perda Provinsi Lampung Nomor 1 Tahun 2010 tentang Rencana Tata Ruang Wilayah Provinsi Lampung Tahun 2009-
2029, Perda Provinsi Lampung Nomor 6 Tahun 2011 tentang Kepariwisataan, dan Perda Provinsi Lampung Nomor 6 Tahun 2012 tentang Rencana Induk Pembangunan Pariwisata Daerah (RIPPDA) Provinsi Lampung. Perda Provinsi Lampung Nomor 1 Tahun 2010 mengatur bahwa, masyarakat berhak ikut serta dalam perencanaan tata ruang, pada proses perencanaan, pemanfaatan, dan pengendalian pemanfaatan ruang, termasuk pemanfaatan wilayah pesisir. ${ }^{63}$ Selain itu RZWP-3K diintegrasikan dengan Rencana Tata Ruang Wilayah (RTRW) ${ }^{64}$ karena kebijakan yang tidak sesuai dengan kaidah tata ruang akan menyebabkan degradasi wilayah pesisir. ${ }^{65}$ Sementara, Perda Provinsi Lampung Nomor 6 Tahun 2011 telah memberikan kesempatan kepada masyarakat untuk berpartisipasi dalam kegiatan pariwisata, yakni dalam proses pengembangan dan pengawasan bidang usaha pariwisata. ${ }^{66}$ Peran serta masyarakat dalam kegiatan pariwisa-

${ }^{58}$ Siti Hajar dkk, Pemberdayaan dan Partisipasi Masyarakat Pesisir, (Medan: Lembaga Penelitian dan Penulisan Ilmiah AQLI, 2018), hlm. 13.

${ }^{59}$ Indonesia. Kementerian Kelautan dan Perikanan Republik Indonesia, Peraturan Menteri Kelautan dan Perikanan tentang Perencanaan Pengelolaan Wilayah Pesisir dan Pulau-Pulau Kecil, Permen KP No. 23/ PERMEN-KP/2016, BN Tahun 2016 No. 1138, ps. 8 ayat (1).

${ }^{60}$ Ibid., ps. 3 huruf d.

${ }^{61}$ Ibid., ps. 17 huruf h.

${ }^{62}$ Ibid., ps. 37 ayat (2) huruf b.

${ }^{63}$ Indonesia. Pemerintah Provinsi Lampung, Peraturan Daerah Provinsi Lampung tentang Rencana Tata Ruang Wilayah Provinsi Lampung Tahun 2009 Sampai 2029, Perda Provinsi Lampung No. 1 Tahun 2010, LD No. 1 Tahun 2010, ps. 157.

${ }^{64}$ Indonesia. Undang-Undang Pengelolaan Wilayah Pesisir dan Pulau-Pulau Kecil, UU No. 27 Tahun 2007, LN No. 84 Tahun 2007, TLN No. 4739, ps. 9 ayat (2).

${ }^{65}$ Rudianto, Buku Ajar Pengelolaan Wilayah Pesisir dan laut Terpadu (PWPLT), (Ponorogo: Uwais Inspirasi Indonesia, 2019), hlm. 7.

${ }^{66}$ Indonesia. Pemerintah Provinsi Lampung, Peraturan Daerah Provinsi Lampung tentang Kepariwisataan, Perda Provinsi Lampung No. 6 Tahun 2011, LD No. 6 Tahun 2011, ps. 58 ayat (1). 
ta dilakukan melalui: peningkatan desa wisata; partisipasi aktif dalam pengembangan pariwisata; penyampaian saran, pendapat, dan aspirasi dalam rangka pengembangan pariwisata; penggalian potensi dan sumber daya ekonomi, kewirausahaan, sosial, seni dan budaya, serta teknologi untuk mendukung kepariwisataan; pembentukan organisasi asosiasi industri dan profesi serta lembaga kemasyarakatan lain untuk mendukung pengembangan pariwisata; serta penyelenggaraan pendidikan dan pelatihan kepariwisataan. ${ }^{67}$ Partisipasi masyarakat ini diharapkan dapat mewujudkan pembangunan pariwisata secara berkelanjutan. Oleh karena itu, masyarakat harus dijadikan subjek dalam pembangunan pariwisata. ${ }^{68}$ Lebih lanjut, melalui Perda Provinsi Lampung Nomor 6 Tahun 2012, pemerintah daerah berupaya mendorong berkembangnya industri kecil masyarakat lokal untuk mendukung pengembangan pariwisata di wilayah pesisir. ${ }^{69}$ Upaya ini dilakukan dengan strategi pengembangan pariwisata Provinsi
Lampung yang di dasarkan pada prinsip pengembangan berbasis masyarakat, ${ }^{70}$ dan memberikan kesempatan yang sama kepada masyarakat untuk terlibat dalam perencanaan, pelaksanaan, dan pengawasan terhadap rencana induk pembangunan pariwisata daerah. ${ }^{71}$

Di sisi lain, Perda Provinsi Lampung Nomor 1 Tahun 2018 memuat arah kebijakan lintas sektor dalam pembangunan pesisir dan pulau-pulau kecil, yang meliputi kegiatan perencanaan, pengelolaan, pengawasan, dan pengendalian terhadap interaksi manusia dalam memanfaatkan sumber daya serta proses alamiah secara berkelanjutan dalam upaya meningkatkan kesejahteraan masyarakat. ${ }^{72}$ Perda Provinsi Lampung Nomor 1 Tahun 2018 mewajibkan, pemerintah daerah menyosialisasikan RZWP-3-K ${ }^{73}$ agar masyarakat dapat berperan serta dalam penyusunan RZWP-3-K dan pemanfaatan ruang wilayah pesisir, dan pengendalian pemanfaatan ruang wilayah pesisir. ${ }^{74}$ Lebih lanjut, dalam penyusunan RZWP-3-K masyarakat dapat memberikan masukan

${ }^{67}$ Ibid., Pasal 59 ayat (1).

${ }^{68}$ Isye Susana Nurhasanah dkk. "Perwujudan Pariwisata Berkelanjutan Melalui Pemberdayaan Masyarakat Lokal di Pulau Pahawang, Pesawaran, Provinsi Lampung," Jurnal Tata Loka, Vol. 19, No. 2, (Mei 2017), hlm. 118.

${ }^{69}$ Indonesia. Pemerintah Provinsi Lampung, Peraturan Daerah Provinsi Lampung tentang Rencana Induk Pembangunan Pariwisata Daerah (RIPPDA) Provinsi Lampung, Perda Provinsi Lampung No. 6 Tahun 2012, LD No. 6 Tahun 2012, TLD No. 369 Tahun 2012, Pasal 16 huruf c.

${ }^{70} \mathrm{Ibid}$., ps. 50 huruf b.

${ }^{71} \mathrm{Ibid} .$, ps. 56 ayat (1).

${ }^{72}$ Indonesia. Pemerintah Provinsi Lampung, Peraturan Daerah Provinsi Lampung tentang Rencana Zonasi Wilayah Pesisir dan Pulau-Pulau Kecil Provinsi Lampung Tahun 2018-2038, Perda Provinsi Lampung Nomor 1 Tahun 2018, LD No. 1 Tahun 2018, ketentuan umum.

${ }^{73} \mathrm{Ibid}$., ps. 80 ayat (2).

${ }^{74}$ Ibid., ps. 82 ayat (2). 
mengenai persiapan penyusunan RZWP-3-K, penentuan arah pengembangan wilayah pesisir, pengidentifikasian potensi dan masalah, perumusan konsepsi RZWP-3-K, dan penetapan RZWP-3-K. ${ }^{75}$ Masyarakat juga dapat melakukan kerja sama dengan pemerintah, pemerintah daerah, maupun dengan sesama unsur masyarakat. ${ }^{76}$ Sedangkan, dalam pemanfaatan wilayah pesisir dan pulau-pulau kecil, masyarakat dapat memberikan masukan dan kerja sama dengan pemerintah dan pemerintah daerah atau sesama unsur masyarakat. ${ }^{77}$ Namun, Perda Provinsi Lampung Nomor 1 Tahun 2018 masih disharmoni dengan peraturan yang lebih tinggi maupun yang setara. Secara vertikal ketidakharmonisan itu berupa tidak diaturnya secara tegas kewajiban pemerintah daerah untuk memfasilitasi masyarakat lokal dan tradisional, belum diaturnya secara tegas tata cara dan bentuk partisipasi masyarakat dalam memberikan usulan RZWP-3-K, dan belum diaturnya kewajiban pemerintah untuk mendorong kegiatan usaha masyarakat pesisir dalam RZWP-3-K dalam Perda Provinsi Lampung Nomor 1 Tahun 2018. ${ }^{78}$ Perda Provinsi Lampung Nomor 1 Tahun 2018 juga belum mengatur secara tegas mengenai peran serta masyarakat dalam pengusulan penyu-

\footnotetext{
${ }^{75}$ Ibid., ps.83 huruf a.

${ }^{76}$ Ibid., ps. 83.

77 Ibid., ps. 85.

${ }^{78}$ Ibid., ps. 63 ayat (1).

${ }^{79}$ Ibid., ps. 83.
}

sunan RZWP-3-K, dan belum mengatur kewajiban pemerintah daerah untuk menyelenggarakan pembinaan dalam rangka peningkatan peran serta dan pemberdayaan masyarakat dalam pengelolaan wilayah pesisir. ${ }^{79}$ Sedangkan secara horizontal ketidakharmonisan itu terjadi karena, Perda Provinsi Lampung Nomor 1 Tahun 2018 tidak mengatur secara jelas peran serta masyarakat dalam setiap kegiatan pembangunan di wilayah pesisir seperti pemanfaatan ruang wilayah pesisir dan kegiatan pariwisata di wilayah pesisir. Terlebih lagi, Perda Provinsi Lampung Nomor 1 Tahun 2018 tidak mengatur secara tegas kewajiban pemerintah daerah untuk mendorong industri kecil masyarakat lokal dalam kegiatan pariwisata di wilayah pesisir.

Berdasarkan uraian di atas, kebijakan pemerintah Provinsi Lampung yang direpresentasikan dalam Perda Provinsi Lampung Nomor 1 Tahun 2018 belum sepenuhnya mengakomodasi hak dan peran serta masyarakat, sebagaimana diamanatkan oleh peraturan perundang-undangan yang lebih tinggi maupun yang setara, yang pada intinya menghendaki pelibatan masyarakat dalam setiap kegiatan pengelolaan wilayah pesisir dan pulau-pulau kecil, baik pada tahap perencanaan, pelaksanaan, pengawasan, 
evaluasi, serta menyampaikan aspirasi sebagai bahan pertimbangan dalam setiap pengambilan keputusan. ${ }^{80} \mathrm{Hal}$ ini menyebabkan minimnya akses bagi masyarakat untuk terlibat dalam pengelolaan wilayah pesisir Lampung. Tingkat kesejahteraan masyarakat pesisir yang masih rendah merupakan implikasi dari minimnya ruang bagi masyarakat untuk terlibat dalam pengelolaan wilayah pesisir. ${ }^{81}$ Implikasi tersebut muncul karena peran serta masyarakat hanya sekadar alat public relation, atau masyarakat hanya digunakan sebagai sarana untuk mencapai tujuan. ${ }^{82}$ Ketidakcermatan penyusun kebijakan menyebabkan terbatasnya akses bagi masyarakat untuk terlibat dalam pengelolaan wilayah pesisir, sehingga hak-hak dan kepentingan masyarakat pesisir terabaikan. Oleh karena itu, integrasi antar peraturan perundang-undangan diperlukan untuk memberikan kepastian hukum, memperkuat pembangunan perekonomian pesisir, dan memberikan kesempatan sebesar-besarnya kepada masyarakat untuk berperan aktif dalam pengelolaan wilayah pesisir. ${ }^{83}$ Dengan demikian, seharusnya hak dan peran serta masyarakat dalam pengelolaan wilayah pesisir yang diatur oleh peraturan perundangan-undangan yang lebih tinggi ${ }^{84}$ dan peraturan perundang-undangan yang setara ${ }^{85}$ tercermin dalam Perda Provinsi Lampung No. 1 Tahun 2018.

\section{Urgensi Harmonisasi Kebijakan Pengelolaan Wilayah Pesisir Lampung}

Pengelolaan wilayah pesisir Lampung yang di atur dalam Perda Provinsi Lampung Nomor 1 Tahun 2018 belum sepenuhnya harmonis dalam mengakomodasi partisipasi masyarakat dalam pengelolaan wilayah pesisir, ${ }^{86}$ sebagaimana diamanatkan oleh peraturan per-

${ }^{80}$ Anak Agung Istri Ari Atu Dewi. “Model Pengelolaan Wilayah Pesisir Berbasis Masyarakat: Community Based Development," Jurnal Penelitian Hukum De Jure, Vol. 18, No. 2, (Juni 2018), hlm. 172.

${ }^{81}$ Endang Sutrisno. "Implementasi Pengelolaan Sumber Daya Pesisir Berbasis Pengelolaan Wilayah Pesisir Secara Terpadu Untuk Kesejahteraan Nelayan," Jurnal Dinamika Hukum, Vol. 14, No. 1, (Januari 2014), hlm. 2.

${ }^{82}$ Lalu Subardi. "Peran Serta Masyarakat dalam Pengelolaan Lingkungan Hidup Menurut Undang-Undang Nomor 32 Tahun 2009 tentang Perlindungan dan Pengelolaan Lingkungan Hidup," Jurnal Yustisia, Vol. 3, No. 1, (Januari-April 2014), hlm. 78.

${ }^{83}$ Cornelia Mirwantini Witomo. "Coastal Management Using Economic Instruments Approach: Theoretical Review and Its Opportunity," Buletin Ilmiah Marina Sosial Ekonomi Kelautan dan Perikanan, Vol. 5, No. 1, (Juni 2019), hlm. 42.

${ }^{84}$ UU WP-3-K, Peraturan Menteri Kelautan dan Perikanan No. 40/PERMEN-KP/2014 dan Peraturan Menteri Kelautan dan Perikanan No. 23/PERMEN-KP/2016.

85 Perda Provinsi Lampung Nomor 1 Tahun 2010 tentang Rencana Tata Ruang Wilayah Provinsi Lampung Tahun 2009-2029, Perda Provinsi Lampung Nomor 6 Tahun 2011 tentang Kepariwisataan, dan Perda Provinsi Lampung Nomor 6 Tahun 2012 tentang Rencana Induk Pembangunan Pariwisata Daerah (RIPPDA) Provinsi Lampung.

${ }^{86}$ Indonesia. Undang-Undang Pengelolaan Wilayah Pesisir dan Pulau-Pulau Kecil, UU No. 1 Tahun 2014, LN No. 2 Tahun 2014, TLN No. 5490, Pasal 60 ayat (1) huruf b dan huruf c serta Pasal 63 ayat (2) 
undang-undangan yang lebih tinggi maupun yang setara. Oleh karena itu, Perda Provinsi Lampung No. 1 Tahun 2018 memerlukan harmonisasi, baik secara vertikal maupun horizontal mengenai keterlibatan masyarakat dalam pengelolaan wilayah pesisir.

Perda Provinsi Lampung Nomor 1 Tahun 2018 memerlukan harmonisasi vertikal karena belum sepenuhnya selaras dengan peraturan perundang-undangan yang lebih tinggi. ${ }^{87} \mathrm{Hal}$ ini karena Perda Provinsi Lampung Nomor 1 Tahun 2018 belum mengatur secara tegas kewajiban pemerintah daerah untuk memfasilitasi masyarakat lokal dan tradisonal dalam pengelolaan wilayah pesisir, belum memuat secara jelas mengenai hak masyarakat atas wilayah penangkapan ikan tradisional dan hak masyarakat untuk memperoleh pembinaan dalam rangka peningkatan peran serta dan pemberdayaan masyarakat dalam pengelolaan wilayah pesisir. Oleh karena itu, reformulasi Perda Provinsi Lampung Nomor 1 Tahun 2018 perlu memperhatikan peraturan perundang-undang yang derajatnya lebih tinggi. Hal ini penting agar rencana zonasi wilayah pesisir dan pulau-pulau kecil Pro- vinsi Lampung selaras dengan pengelolaan wilayah pesisir dan pulau-pulau kecil, peran serta dan pemberdayaan masyarakat dalam pengelolaan wilayah pesisir dan pulau-pulau kecil, dan perencanaan pengelolaan wilayah pesisir dan pulau-pulau kecil. Apabila harmonisasi vertikal ini gagal, maka akan menimbulkan tumpang tindih peraturan dan memberikan peluang untuk dilakukan judicial review $w^{88}$ terhadap Perda Provinsi Lampung Nomor 1 Tahun 2018. Lebih lanjut, harmonisasi vertikal Perda Provinsi Lampung Nomor 1 Tahun 2018 diperlukan guna mencegah konflik antar kepentingan. Terlebih di era otonomi daerah ini, dalam menetapkan peraturan pemerintah daerah cenderung berdasarkan kepentingannya untuk meningkatkan pendapatan asli daerah (PAD). Kondisi ini dikhawatirkan menimbulkan ketidakpastian hukum dalam pengelolaan wilayah pesisir yang dapat berujung pada kerusakan sumber daya dan ekosistem pesisir. ${ }^{89}$

Selain itu, Perda Provinsi Lampung Nomor 1 Tahun 2018 memerlukan harmonisasi horizontal karena masih disharmoni dengan peraturan sektoral Provinsi Lampung. ${ }^{90}$ Perda Provinsi Lampung

\footnotetext{
87. UU WP-3-K, Permen KP No. 40/PERMEN-KP/2014, dan Permen KP No. 23/PERMEN-KP/2016

${ }^{88}$ Soegiyono, Pentingnya Harmonisasi Pembentukan Peraturan Perundang-Undangan, (Jakarta: Pusat Kajian Kebijakan Penerbangan dan Antariksa, 2015), hlm. 13.

${ }^{89}$ Luky Adrianto dkk, Laporan Analisis dan Evaluasi Hukum tentang Pengelolaan Wilayah Pesisir dan Pulau-Pulau Kecil, (Jakarta: Pusat Perencanaan Pembangunan Hukum Nasional Badan Pembinaan Hukum Nasional, 2015), hlm. 24-25.
} 
Nomor 1 Tahun 2018 belum memuat secara jelas peran serta masyarakat dalam setiap kegiatan pembangunan di wilayah pesisir baik mengenai penyusunan rencana tata ruang, pengawasan pemanfaatan ruang, dan kegiatan pariwisata di wilayah pesisir.

Seharusnya, pada saat penyusunan Perda Provinsi Lampung No. 1 Tahun 2018, dilakukan koordinasi dengan instansi terkait mengenai substansi hukum yang akan diatur. ${ }^{91} \mathrm{Hal}$ ini tentunya bisa dikoreksi pada saat peninjauan kembali/revisi Perda Provinsi Lampung No. 1 Tahun 2018 yang dilakukan setiap 5 (lima) tahun. ${ }^{92}$ Nantinya, reformulasi Perda Provinsi Lampung No. 1 Tahun 2018 harus memperhatikan peraturan sektoral di Provinsi Lampung. Hal ini penting agar rencana zonasi wilayah pe- sisir Lampung selaras dengan rencana tata ruang dan pariwisata. Apabila harmonisasi horizontal ini gagal, maka akan terjadi tumpang tindih peraturan antar sektor ${ }^{93}$ yang menyebabkan inkonsistensi dalam interpretasi dan implementasi. ${ }^{94}$ Kondisi ini menyebabkan ketidakpastian hukum dan ambiguitas dalam penerapannya. Selain itu, harmonisasi horizontal Perda Provinsi Lampung No. 1 Tahun 2018 dengan peraturan sektoral Provinsi Lampung mengenai keterlibatan masyarakat dalam pengelolaan wilayah pesisir, berfungsi untuk menghindari dualisme peraturan yang dapat menggagalkan tujuan negara untuk menciptakan kesejahteraan sosial bagi seluruh rakyat Indonesia. ${ }^{95}$ Mengingat Perda Provinsi Lampung Nomor 1 Tahun 2018 telah diundangkan pada tahun 2018,

\footnotetext{
${ }^{90}$ Perda Provinsi Lampung Nomor 1 Tahun 2010 tentang Rencana Tata Ruang Wilayah Provinsi Lampung Tahun 2009 sampai dengan Tahun 2029, Perda Provinsi Lampung Nomor 6 Tahun 2011 tentang Kepariwisataan, dan Perda Provinsi Lampung Nomor 6 Tahun 2012 tentang Rencana Induk Pembangunan Pariwisata Daerah (RIPPDA) Provinsi Lampung.

${ }^{91}$ Lembaga Penelitian dan Pengabdian Kepada Masyarakat Institut Pertanian Bogor (LPPM IPB), Kajian Gerakan Membangun Pesisir Lampung Berdaya Guna "GERBANG PELANA", (Bogor: LPPM IPB, 2017), hlm. 24.

${ }_{92}^{2}$ Indonesia. Undang-Undang Pengelolaan Wilayah Pesisir dan Pulau-Pulau Kecil, UU No. 27 Tahun 2007, LN No. 84 Tahun 2007, TLN No. 4739, ps. 9 ayat (4).

${ }_{93}$ Contoh Kementerian Dalam Negeri RI merasa memiliki kompetensi dalam memberikan advis terhadap Perda tentang Organisasi Pemerintahan Daerah. Padahal Kementerian lain sepatutnya perlu dimintai pendapat terkait pemisahan, penggabungan, atau penghilangan bidang-bidang dalam penyelenggaraan pemerintah daerah. Fakta lainnya menunjukkan beberapa Perda Provinsi, Kabupaten/Kota di Kalimantan Timur disharmonis, diantaranya Perda tentang Pembentukan Peraturan Daerah, Perda tentang Pengelolaan Barang Milik Daerah, Perda tentang Penyelenggaraan Jalan Umum dan Jalan Khusus untuk Kegiatan Pengangkutan Batubara dan Kelapa Sawit, dan Perda tentang Pengelolaan Barang Milik Daerah Provinsi Kalimantan Timur.

${ }^{94}$ Ida Bagus Rahmadi Supanca, Berbagai Perspektif Harmonisasi Hukum Nasional dan Hukum Internasional, (Jakarta: Universitas Katolik Indonesia Atma Jaya, 2019), hlm. 2.

${ }_{95}^{5}$ Elviandri dkk, "Quo Vadis Negara Kesejahteraan: Meneguhkan Ideologi Walfare State Negara Hukum Kesejahteraan Indonesia", Mimbar Hukum, Vol. 31, No. 2 (Juni 2019), hlm. 253.
} 
maka harmonisasi dilakukan pada saat peninjauan kembali. Peninjauan kembali terhadap Perda RZWP-3-K merupakan amanat Undang-Undang Nomor 27 Tahun 2007 yang dilakukan setiap 5 (lima) tahun. ${ }^{96}$ Ketentuan ini kemudian diadopsi oleh Perda Provinsi Lampung Nomor 1 Tahun 2018, yang menyatakan bahwa peninjauan kembali RZWP-3-K dilakukan 1 (satu) kali dalam 5 (lima) tahun. ${ }^{97}$ Namun peninjauan kembali terhadap RZWP-3-K dapat dilakukan lebih dari satu kali dalam lima tahun apabila terjadi bencana alam skala besar, perubahan batas teritorial negara, dan perubahan batas wilayah daerah yang ditetapkan dengan undang-undang. ${ }^{98}$ Karena ketiga kondisi tersebut tidak terjadi pada saat ini, maka Tahun 2023 adalah momentum untuk melakukan perubahan dengan pengharmonisan Perda Provinsi Lampung Nomor 1 Tahun 2018 dengan peraturan perundang-undangan yang lebih tinggi, maupun pengharmonisan dengan peraturan perundang-undangan yang setara terkait pelibatan masyarakat dalam pengelolaan wilayah pesisir.

\section{Penutup}

Berdasarkan uraian di atas, Perda Provinsi Lampung No. 1 Tahun 2018 belum sepenuhnya selaras dengan peraturan perundang-undangan yang lebih tinggi (disharmoni vertikal) yakni UU WP-3-K, Permen KP No. 40/PERMEN-KP/2014, dan Permen KP No. 23/PERMEN-KP/2016. Selain itu Perda Provinsi Lampung Nomor 1 Tahun 2018 belum sepenuhnya selaras dengan peraturan perundang-undangan yang setara (disharmoni horizontal) yaitu Perda Provinsi Lampung Nomor 1 Tahun 2010, Perda Provinsi Lampung Nomor 6 Tahun 2011, dan Perda Provinsi Lampung Nomor 6 Tahun 2012.

Disharmoni ini menimbulkan beberapa dampak dalam pengelolaan wilayah pesisir Lampung. Pertama, tumpang-tindihnya peraturan menimbulkan ketidakpastian hukum bagi masyarakat untuk berperan aktif dalam pengelolaan wilayah pesisir. Kedua, mengakibatkan kesenjangan dalam hal peruntukan dan pemanfaatan sumber daya pesisir. Kondisi ini berpotensi menimbulkan konflik antar pemangku kepentingan (masyarakat, pemerintah, dan pengusaha). Ketiga, terbatasnya akses masyarakat un-

\footnotetext{
${ }^{96}$ Indonesia. Undang-Undang Pengelolaan Wilayah Pesisir dan Pulau-Pulau Kecil, UU No. 27 Tahun 2007, LN No. 84 Tahun 2007, TLN No. 4739, ps. 9 ayat (4).

${ }^{97}$ Indonesia. Pemerintah Provinsi Lampung, Peraturan Daerah Provinsi Lampung tentang Rencana Zonasi Wilayah Pesisir dan Pulau-Pulau Kecil Provinsi Lampung Tahun 2018-2038, Perda Provinsi Lampung Nomor 1 Tahun 2018, LD No. 1 Tahun 2018, ps. 5 ayat (2).

${ }^{98}$ Ibid., ps. 5 ayat (3).
} 
tuk berperan serta dalam pengelolaan wilayah pesisir Lampung. Kondisi ini menyebabkan pengelolaan wilayah pesisir Lampung tidak optimal dan tidak terintegrasi dengan kebutuhan masyarakat di wilayah pesisir. ${ }^{99}$ Dengan minimnya peran serta masyarakat, pengelolaan wilayah pesisir Lampung secara berkelanjutan sulit untuk diwujudkan, karena masyarakat adalah unsur penting dalam pembangunan berkelanjutan. ${ }^{100}$ Oleh karena itu guna mewujudkan pe- ngelolaan wilayah pesisir yang berbasis masyarakat, Perda Provinsi Lampung Nomor 1 Tahun 2018 perlu diperbaiki melalui harmonisasi norma hukum, baik secara vertikal maupun horizontal terkait keterlibatan masyarakat dalam pengelolaan wilayah pesisir. Mengingat Perda Provinsi Lampung Nomor 1 Tahun 2018 telah berlaku, maka upaya harmonisasi ini dapat dilakukan pada saat peninjauan kembali atau revisi.

${ }^{99}$ Aris Subagiyo, Pengelolaan Wilayah Pesisir dan Pulau-Pulau Kecil, (Malang: Universitas Brawijaya Press, 2017), hlm. 12.

${ }^{100}$ Anak Agung Istri Ari Atu Dewi. "Community Based Development: Community-Based Coastal Area Management Model," Jurnal Penelitian Hukum De Jure, Vol. 18, No. 2, (Juni 2018), hlm. 174. 
Harmonisasi Kebijakan Pengelolaan Lingkungan Pesisir Lampung dalam Rezim Pengelolaan Berbasis Masyarakat

\section{DAFTAR PUSTAKA}

\section{Peraturan Perundang-Undangan}

Indonesia. Undang-Undang Pengelolaan Wilayah Pesisir dan Pulau-Pulau Kecil. UU No. 27 Tahun 2007. LN No. 84 Tahun 2007. TLN No. 4739.

\section{Undang-Undang Pengelolaan}

Wilayah Pesisir dan Pulau-Pulau Kecil.

UU No. 1 Tahun 2014. LN No. 2

Tahun 2014. TLN No. 5490.

Undang-Undang Pemerintahan

Daerah. UU No. 23 Tahun 2014. LN

No. 244 Tahun 2014. TLN No. 5587.

Menteri Kelautan dan

Perikanan. Peraturan Menteri

Kelautan dan Perikanan tentang

Peran Serta Dan Pemberdayaan

Masyarakat Dalam Pengelolaan

Wilayah Pesisir Dan Pulau-Pulau

Kecil. No. 40 Tahun 2014.

Menteri Kelautan dan

Perikanan. Peraturan Menteri

Kelautan dan Perikanan tentang

Perencanaan Pengelolaan Wilayah

Pesisir Dan Pulau-Pulau Kecil. No.

23 Tahun 2016.

Pemerintah Provinsi Lampung.

Peraturan Daerah Provinsi Lampung tentang Rencana Zonasi Wilayah Pesisir dan Pulau-Pulau Kecil Provinsi Lampung 2018-2038. No. 1 Tahun 2018.

Pemerintah Provinsi Lampung. Peraturan Daerah Provinsi Lampung tentang Rencana Tata Ruang Wilayah (RTRW) Provinsi Lampung Tahun 2009 Sampai Dengan 2029. No. 1 Tahun 2010.
Pemerintah Provinsi Lampung. Peraturan Daerah Provinsi Lampung tentang Kepariwisataan. No. 6 Tahun 2011.

Pemerintah Provinsi Lampung. Peraturan Daerah Provinsi Lampung tentangRencanaIndukPembangunan Pariwisata Daerah (RIPPDA). No. 6 Tahun 2012.

\section{Buku}

Adrianto, Luky dkk, Analisis dan Evaluasi Hukum tentang Pengelolaan Wilayah Pesisir dan Pulau-Pulau Kecil, Jakarta: Badan Pembinaan Hukum Nasional Kementerian Hukum dan HAM RI, 2015.

Eksekutif Daerah WALHI Lampung. Pesisir Laut dan Pulau-Pulau Kecil Lampung. Kertas posisi isu pengelolaan wilayah pesisir laut dan pulau-pulau kecil Lampung. Bandar Lampung: Eksekutif Daerah WALHI Lampung.

Hajar, Siti dkk, Pemberdayaan dan Partisipasi Masyarakat Pesisir, Medan: Lembaga Penelitian dan Penulisan Ilmiah AQLI, 2018.

Lembaga Penelitian dan Pengabdian Kepada Masyarakat Institut Pertanian Bogor (LPPM IPB). Kajian Gerakan Membangun Pesisir Lampung Berdaya Guna "GERBANG PELANA". Bogor: LPPM IPB. 2017.

Supanca, Ida Bagus Rahmadi, Berbagai PerspektifHarmonisasi Hukum Nasional dan Hukum Internasional, Jakarta: Universitas Katolik Indonesia Atma Jaya, 2019. 
Rudianto, Buku Ajar Pengelolaan Wilayah Pesisir dan laut Terpadu (PWPLT), Ponorogo: Uwais Inspirasi Indonesia, 2019.

Satria, Arif, Pengantar Sosiologi Masyarakat Pesisir, Jakarta: Yayasan Pustaka Obor Indonesia, 2015.

Soegiyono, Pentingnya Harmonisasi Pembentukan Peraturan PerundangUndangan, Jakarta: Pusat Kajian Kebijakan Penerbangan dan Antariksa, 2015.

Subagiyo, Aris, Pengelolaan Wilayah Pesisir dan Pulau-Pulau Kecil, Malang: Universitas Brawijaya Press, 2017.

Theresia, Aprillia dkk, Pembangunan Berbasis Masyarakat: Acuan bagi Praktisi, Akademisi, dan Pemerhati Pengembangan Masyarakat, Bandung: Alfabeta, 2014.

\section{Artikel Jurnal}

Amarini, Indriati. “Evaluasi Aktualisasi Pancasila Melalui Harmonisasi Hukum," Jurnal Kosmik Hukum, Vol. 17, No. 2, Juni 2017.

Ari Atu Dewi, Anak Agung Istri. "Model Pengelolaan Wilayah Pesisir Berbasis Masyarakat: Community Based Development," Jurnal De Jure, Vol. 18, No. 2, Juni 2018.

Arieta, Siti. "Co-Management dalam Arena Perikanan Napoloen Wrasse di Kabupaten Kepulauan Anambas Tinjaun Teoritis dalam Mewujudkan Keberlanjutan Lingkungan Maritim," Jurnal PPNS, Vol. 4, No. 1, Desember 2019.
Budoyo, Sapto. "Konsep Langkah Sistemik Harmonisasi Hukum Dalam Pembentukan Peraturan PerundangUndangan," Jurnal Ilmia CIVIS, Vol. 4, No. 2, Juli 2014.

Elviandri dkk, “Quo Vadis Negara Kesejahteraan: Meneguhkan Ideologi Walfare State Negara Hukum Kesejahteraan Indonesia", Mimbar Hukum, Vol. 31, No. 2, Juni 2019.

Febriansyah, Ferry Irawan. “Konsep Pembentukan Peraturan PerundangUndangan Di Indonesia," Jurnal Pespektif, Vol. 21, No. 3, September 2016.

Heryandi dkk. "Harmonization of Village Development Planning Law in Lampung Coastal in the Spatial Planning Regime," Journal of Law, Policy, and Globalization, Vol. 70, 2018. Igir, Angreime. "Pembatalan Terhadap Peraturan Daerah Menurut UndangUndang Nomor 23 Tahun 2104," Lex Privatum, Vol. 5, No. 3, Mei 2017.

Iswahyuni, Ari. "Kedudukan Ancaman Pidana Minimal Dalam UndangUndang Nomor 35 Tahun 2009 tentang Narkotika Pasca Dikeluarkannya Surat Edaran Mahkamah Agung Nomor 3 Tahun 2015," Jurnal Panorama Hukum, Vol. 3, No. 1, Juni 2018.

Nur, Insan Tajali. "Memantapkan Landasan Hukum Formil sebagai Alat Sinkronisasi dan Harmonisasi Peraturan Perundang-undangan," Yuriska: Jurnal Ilmiah Hukum, Vol. 10, No. 2, 2018. 
Nurhasanah, Isye Susana. "Perwujudan Pariwisata Berkelanjutan Melalui Pemberdayaan Masyarakat Lokal di Pulau Pahawang , Pesawaran, Provinsi Lampung," Jurnal Tata Loka, Vol. 19, No. 2, Mei 2017.

Priyanta, Maret. "Pembaharuan dan

Harmonisasi Peraturan PerundangUndangan Bidang Lingkungan dan Penataan Ruang Menuju Pembangunan Berkelanjutan," Hasanudin Law Review, Vol. 1, No. 3, Desember 2015.

Sopyan, Y. "Corporate Social Responsibility (Csr) Sebagai Implementasi Fikih Sosial Untuk Pemberdayaan Masyarakat," AHKAM : Jurnal Ilmu Syariah, Vol. 14, No. 1, Januari 2014.

Sukma, Novira Maharani. "Analisis Yuridis Pembatalan Perda Oleh Menteri Dalam Negeri," Jurnal Ilmiah Galuh Justisi, Vol. 5, No. 1, Maret 2017.

Sutrisno, Endang. "Implementasi Pengelolaan Sumber Daya Pesisir Berbasis Pengelolaan Wilayah Pesisir Secara Terpadu Untuk Kesejahteraan Nelayan," Jurnal Dinamika Hukum, Vol. 14, No. 1, Januari 2014.
Trinanda, Tommy Cahya. "Pengelolaan Wilayah Pesisir Indonesia dalam Rangka Pembangunan Berbasis Pelestarian Lingkungan," Matra Pembaharuan: Jurnal Inovasi Kebijakan, Vol. 1, No. 2, 2017.

Witomo, Cornelia Mirwantini. "Coastal Management Using Economic Instruments Approach: Theoretical Review and Its Oppurtunity," Buletin Ilmiah Marina Sosial Ekonomi Kelautan dan Perikanan, Vol. 5, No. 1, Juni 2019.

\section{Lain-Lain}

Indonesian Center for Environmental Law. "Kerangka Hukum: Pelibatan Masyarakat dalam Penyusunan Rencana Zonasi Wilayah Pesisir dan Pulau-Pulau Kecil," https://icel.or. id/wp-content/uploads/lembarinformasi-pelibatan-masyarakat.pdf, diakses pada 3 April 2020.

Rencana Pembangunan Jangka Menengah Daerah (RPJMD) Provinsi Lampung 2015-2019.

Soegiyono, "Pentingnya Harmonisasi Pembentukan Peraturan PerundangUndangan",https:/ / puskkpa.lapan. go.id/files_arsip/Soegiyono_ Pentingnya_Harmoniasi_2015.pdf, diakses tanggal 1 April 2020. 